\title{
Effect of ground squirrel burrows on plant productivity in a cool desert environment
}

\author{
JOHN W. LAUNDRE
}

Author has a joint appointment as a research assistant professor at the Department of Biological Sciences, ldaho State University, Pocatello, Ida. 83209 and a visiting research associate at the Instituto de Ecologia, A.C., A.P. 63, 91000, Xalapa, Veracruz, Mexico.

\begin{abstract}
Previous work demonstrated that burrows of Townsend's ground squirrels (Spermophilus townsendii Merriam) in cool deserts increased the amount of spring recharge of soil moisture compared to areas without burrows. The objective of this study was to test the hypothesis that this additional soil moisture would enhance plant productivity. I compared productivity of western wheatgrass (Agropyron smithii Rydb.) and big sagebrush (Artemisia tridentata Nutt.) plants adjacent to burrows to plants in areas lacking burrows. Grass productivity was estimated within an experimental grid containing cells of either $0,2,4$, or 6 artificial burrows and was based on measures of annual above ground biomass production and number of seed heads produced. For sagebrush, productivity was estimated from bushes without burrows (controls) and ones having a natural burrow near their base. Sagebrush productivity was based on average length of new annual terminal growth of vegetative stems. The mean annual estimates of grass biomass $\left(50.0 \mathrm{~g} \mathrm{~m}^{-2}\right.$ year-1, $\left.\mathrm{SE}=11.8\right)$ was significantly higher in test grid cells with the highest number of artifi-

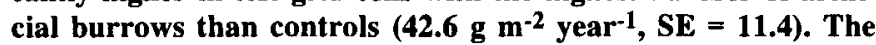
mean of annual estimates of sagebrush stem growth for bushes adjacent to burrows was a significant $0.6 \mathrm{~cm}(\mathrm{SE}=0.11)$ longer than bushes without burrows. I conclude that the added moisture from spring recharge at ground squirrel burrows can increase plant productivity in a cool desert environment.
\end{abstract}

Key Words: ground squirrel, plant productivity, sagebrush, Idaho, cool desert

Small mammals via their burrowing activity, can alter a variety of soil characteristics including ion exchange capacity, water holding capacity, organic matter, and inorganic nutrient levels (Greene and Reynard 1932, Taylor 1935, Thorp 1949, Turner et al. 1973 Grant 1974, Chew 1978 Huntly and Inouye 1988, Inouye et al. 1987). Additionally, in arid environments, burrows of small mammals enhance water infiltration and increase the amount of moisture stored in the soil profile (Turner et al. 1973, Laundre 1993) especially during spring snow melt. Infiltration of water

Research was funded by the Division of Waste Programs, U.S. Department of Energy through the Environmental Science and Research Foundation, Idaho Falls, Ida. Author wishes to thank Dr. Jay Anderson, Dr. Roger D. Blew, Dr. O. Doyle Markham, Dr. Timothy D. Reynolds, and Dr. Randy Morris for critically reviewing the manuscript.

Manuscript accepted 3 Jan. 1998. during this spring "recharge" provides the most significant addition of moisture to this zone (Anderson et al. 1987).

In arid environments, it has been demonstrated that the amount of moisture available within the rooting zone limits biomass and seed productivity of plants (Bamberg et al. 1976, Lane et al. 1984). Consequently, it would be predicted that the added soil moisture from the presence of burrows should significantly increase plant productivity. This prediction, however, has yet to be tested. Here, I propose to test the hypothesis that the presence of small mammal burrows enhances biomass productivity by comparing productivity measurements of sagebrush (Artemisia tridentata Nutt.) and western wheatgrass (Agropyron smithii Rydb.) in areas adjacent to burrows of Townsend's ground squirrels (Spermophilus townsendii Merriam) to non burrow control areas.

Testing of the hypothesis of burrows affecting plant productivity is contingent on the initial hypothesis that the productivity measurements to be used for the 2 species are positively affected by increasing soil moisture levels. Biomass production in a variety of grass species has been shown to be directly related to soil moisture (Rogler and Haas 1947, Sneva and Hyder 1962, Currie and Peterson 1966, Shiflet and Dietz 1974) but not for the species used here. Regarding biomass production in sagebrush, Bamberg et al. (1976) found that a 4 times difference in precipitation between 2 growing seasons resulted in a 3.5 to 900 times higher amount of stem biomass for 4 shrub species, not including sagebrush, in the Mojave Desert. However, Evans and Black (1993) found no difference in nonreproductive biomass for sagebrush under 2 different moisture regimes within the same year. Because of the lack of data for western wheatgrass and the conflicting data for shrubs, before testing the main hypothesis, I first had to test the initial hypothesis that increased soil moisture increased the productivity measurements for these 2 species.

\section{Methods}

\section{Study area}

The study was conducted between 1986 and 1993 on the Idaho National Engineering and Environmental Laboratory (INEEL). The INEEL is a $2,300 \mathrm{~km}^{2}$ National Environmental Research Park operated by the U.S. Department of Energy and is located approximately $65 \mathrm{~km}$ northwest of Pocatello, Ida. Vegetation on the INEEL is a mixture of sagebrush and native grasses typical of the Columbia and Snake River Plains (Anderson and Holte 1981). Annual precipitation on the INEEL during the study aver- 
aged $22 \mathrm{~cm}$ with approximately $50 \%$ falling in the months of September to March. Precipitation in these months prior to the 8 surnmers in which productivity was measured ranged from 4.6 $\mathrm{cm}$ to $14.5 \mathrm{~cm}$.

\section{Experimental designs}

Two experimental designs were used to test the main hypothesis. In the first, productivity of individual sagebrush plants within $30 \mathrm{~cm}$ of single, natural Townsend's ground squirrel burrows (treatment) was compared to productivity of sagebrush without burrows (controls). There were a total of 15 pairs (replicates) of controls and treatments located in 2 siles separated by approximately 3 kilometers and representative of sagebrush steppe. In the second design, productivity of western wheatgrass was compared among $1 \mathrm{~m}^{2}$ plots containing either $0,2,4$, or 6 artificial ground squirrel burrows. The plots were within a uniform stand of western wheatgrass located at the Environmental Science and Research Foundation Experimental Field Station. The artificial burrows were dug with a standard soil sampling auger. Dimensions of the burrows were similar to average Townsend's ground squirrel burrows: $5.0 \mathrm{~cm}$ in diameter, $30 \mathrm{~cm}$ deep, and slanted at a $45^{\circ}$ angle (Laundre 1993). Each plot was a cell in a grid with a $2.0-\mathrm{m}$ buffer separating adjacent cells (Laundre 1993). There were 8 replicates per treatment. Each treatment replicate was randomly assigned within the $4 \times 8$ cell experimental grid. Densities of burrows of Townsend's ground squirrels likey do not reach those of the higher density plots. However, they were included in this study to determine possible effects of highly colonial species or species which construct multiple openings to their burrows.

Estimates of productivity in sagebrush were based on length of annual terminal tip growth (cm/year) of vegetative stems. At the end of the growing season (August/September) lengths of 10 randomly chosen terminal branches per plant were measured and averaged. Productivity of wheatgrass was assessed by clipping and weighing above ground biomass in August/September. I also counted the number of seed heads produced by the end of the growing season as an index of reproductive productivity. Above ground biomass was subsampled from 10 randomly chosen 100 $\mathrm{cm}^{2}(10 \mathrm{~cm} \times 10 \mathrm{~cm})$ cells $\left(10 \%\right.$ of total area) within each $1.0 \mathrm{~m}^{2}$ test grid cell. The subsamples were air dried 2 months and then weighed $(\mathrm{g})$, averaged, and multiplied by 100 to obtain an estimate of the biomass $\left(\mathrm{g} \mathrm{m}^{-2}\right.$ year-1) of the test grids. Seed head production (\# $\mathrm{m}^{-2}$ year ${ }^{-1}$ ) within each $1.0 \mathrm{~m}^{2}$ grid cell was calculated by counting all heads present within the grid cells at the time of biomass sampling. The experimental grid cells were mowed each year in late February prior to the beginning of the growing season to remove above ground biomass left from the previous year.

A neutron probe (Campbell Nuclear Pacific Corp., Pacheco, Calif, USA) was used to estimate soil moisture. Access tubes for the probe were placed within $10 \mathrm{~cm}$ of burrows and/or sagebrush and centered within each grid cell of the wheatgrass grid (Laundre 1993). Probe readings were taken at $20 \mathrm{~cm}$ intervals to a depth of $180 \mathrm{~cm}$. Percent moisture (by volume) estimates were based on a field derived calibration equation. The fractional counterparts of percent moisture were multiplied by 20 to obtain estimates of the amount of moisture in the soil in the interval 10 $\mathrm{cm}$ above to $10 \mathrm{~cm}$ below a sample point. All estimates were summed to calculate the total moisture in the profile. Moisture added to the soil profile from spring recharge was calculated as the difference between soil moisture levels immediately after snow melt and moisture levels in the profile the previous fall, September/October (Laundre 1993).

\section{Statistical designs}

To avoid pseudo-replication, all estimates for the replicates within a given category, e.g. 15 estimates for sagebrush control or 8 estimates for wheatgrass control, for a given year, were averaged to yield single annual mean estimates for each of the study years under natural precipitation. These annual mean estimates were used for all calculations. For the sagebrush experiment there were 6 annual estimates (1987-91 \& 1993); no average estimate was available for 1992 because of the lack of sagebrush growth. For the wheatgrass design there were 7 annual estimates (1986-90 \& 1992-93).

I tested the initial relationship between increased soil moisture and the productivity measurements recorded with a simple linear regression design. For each regression, the annual mean estimate of a productivity measurement (above ground biomass, seed head production, and terminal vegetative stem growth) was the dependent variable and corresponding annual mean recharge estimates ( $\mathrm{cm}$ of soil moisture) the independent variable. These tests were to initially determine if and to what extent increases in soil moisture had an effect on the various plant productivity measurements. To reduce any complicating affects that burrows may have on plant productivity, only annual mean productivity and moisture recharge data from controls, no burrows, for the sample years under natural precipitation were used for these analyses. In February 1991, snow pack levels were augmented with a snow making machine on the grass test grid and on several of the sagebrush pairs. The snow levels were uneven and within the same year provided differing moisture recharge levels. Individual moisture recharge and productivity estimates, rather than means, for 7 of the controls in the grass and 4 of the controls in the sagebrush areas from that year were included with annual means in the appropriate analyses. For sagebrush, these 4 individual estimates were not included in calculating the annual mean of that year because of their extremely high values. The hypothesis tested was that increased soil moisture resulted in higher plant productivity; consequently a one-tailed rejection level was used to test the null regression hypothesis of $\beta \leq 0.0$.

For the main hypothesis to be tested, estimates of annual mean vegetative stem growth of sagebrush were compared between burrow sites and sites without burrows with a one-tailed, paired-t statistical design. As the hypothesis tested stem growth of the treatment is longer than the control, the null hypothesis was the mean difference between treatment minus control was $\leq 0.0$. The annual mean estimates among the control and three treatments for above ground wheatgrass biomass and seed head production were individually compared with a repeated measures one way analysis of variance design. The Student-Neumann-Kuels multiple range test was used to isolate groups when the null hypothesis of equal means was rejected. The $\mathrm{P} \leq 0.05$ rejection level was used and all tests were conducted with the use of the Sigmastat statistical package (Fox et al. 1995).

Although it has been shown that natural burrows on average, significantly increased moisture recharge (Laundre 1993), amount of moisture added to the soil at some hurrows in some years were found to be lower then controls. Differences in snow 
pack levels, snow melt patterns, micro topography, etc can affect the impact of individual burrows on recharge amounts for a given spring. The main purpose of the sagebrush experimental design was to determine if increased soil moisture at burrow sites enhanced plant productivity. Including productivity measurements from a data pair where moisture levels were higher for the control could affect the ability to critically test the desired hypothesis and delineate the total impact of burrows on productivity. Consequently, after first comparing productivity levels at control and treatments of all data pairs of sagebrush, I separated out the data pairs in which recharge levels were higher for treatments than controls and re-compared productivity estimates for this subset. For the remaining pairs, where recharge amounts were higher at controls, it would be predicted that plant productivity would also be higher. I tested this ancillary hypothesis by comparing productivity within this subset (one-tailed paired-t).

Significant differences in productivity between treatments and controls for both designs need not be the sole result of the higher soil moisture from spring recharge. Other factors, such as increased soil aeration or nutrient cycling at burrow sites, might produce similar effects. If, however, productivity differences are related to soil moisture alone, i.e. the main hypothesis is supported, a significant positive regression should exist for the differences between annual mean treatment and control values of that productivity measurement and corresponding differences between annual mean treatment and control measurements of moisture recharge levels. To test this, I subtracted control productivity values from their corresponding treatment values for each sample year. I did the same for the corresponding soil moisture recharge values. This produced a set of paired differences between treatment and control for a given productivity measurement (e.g. biomass) and soil moisture for each sample year. I then regressed the differences in productivity (dependent variable) to the paired difference in soil moisture (independent variable). As a significant positive regression is being predicted, a one-tailed rejection level was used to test the null of a slope $(\beta)$ of zero or less.

\section{Adequacy of sample sizes}

The adequacy of the subsample size $\left(100 \mathrm{~cm}^{2}\right)$ and number of subsamples (10) used to accurately estimate above ground biomass of grass within the $1 \mathrm{~m}^{2}$ plots was determined in the first year of the study (1986). I subsampled 20 such cells ( $20 \%$ of total area) per test plot for 16 plots and then analyzed the running mean (Briggs and Knapp 1991) to determine at what sample size the resulting curve began to stabilize. I conducted a similar analysis for the sagebrush subsamples.

To determine the minimum number of replicates per treatment needed to discern a statistical difference among treatments in both experiments, I again conducted an analysis of the running mean and, in addition, of the standard error (Briggs and Knapp 1991). In the first year of the study, I estimated grass biomass production from 16 plots without artificial burrows and sagebrush growth from 15 control sites. I then randomly selected the order in which these plots/sites would be added to calculations of the running mean and standard error. I replicated this procedure 5 times, obtaining 5 estimates of the running mean and standard error for each experimental design.

\section{Results}

\section{Sample size adequacy}

For the estimate of subsample adequacy in the wheatgrass expcriment, the curve for the running average deflected and began to stabilize at 10 subsamples. The biomass estimates at this number of subsamples for the 16 plots was compared with the estimates from 20 subsamples (paired-t) and the difference between the means was not significant $\left(\bar{x}_{10}=74.2 \mathrm{~g} \mathrm{~m}^{-2}\right.$ year-1, $\mathrm{SE}=3.27, \mathrm{n}=16, \bar{x}_{20}=71.9 \mathrm{~g} \mathrm{~m}^{-2}$ year ${ }^{-1}, \mathrm{SE}=2.67, \overline{\mathrm{x}}_{\text {diff }}$ diff $=$ $2.3 \mathrm{~g} \mathrm{~m}^{-2}$ year ${ }^{-1}, \mathrm{t}=0.941$ ). It was concluded that $10,100 \mathrm{~cm}^{2}$ subsamples per test plot were sufficient to estimate biomass production of a whole $1 \mathrm{~m}^{2}$ plot. A similar analysis for 11 sagebrush individuals indicated a deflection in the curve at 8 measurements of terminal stem growth and there was no significant difference between the means for 8 and 10 measurements $\left(\mathrm{x}_{8}=1.4 \mathrm{~cm}\right.$ year-1, $\mathrm{SE}=0.17, \overline{\mathrm{x}}_{10}=1.5 \mathrm{~cm}_{\mathrm{year}}{ }^{-1}, \mathrm{SE}=0.17, \overline{\mathrm{x}}_{\mathrm{diff}}=0.03, \mathrm{SE}=0.02, \mathrm{t}$ $=1.33, P=0.21)$. Consequently, 10 measurements of terminal stem growth were considered adequate to assess the average for a given sagebrush individual.

With regard to the adequacy of plot replicates, for the grass plots, the point of inflection in the curves for the running mean occurred at 7-8 plots and the standard error became $<10 \%$ of the mean at 8 plots $\left(\bar{x}_{8}=71.0, \mathrm{SE}=6.94, \bar{x}_{16}=70.4, \mathrm{SE}=5.62\right)$. The point of inflection in the running mean for sagebrush estimates occurred at 12 sagebrush samples but the standard error was not consistently $<10 \%$ of the mean for the 5 random runs until 15 samples $\left(\bar{x}_{12}=3.36 \mathrm{~cm}_{\text {year-1, }} \mathrm{SE}=0.34, \overline{\mathrm{x}}_{15}=3.28 \mathrm{~cm}\right.$ year $^{-1}, \mathrm{SE}=0.29$ ). This analysis indicated that 8 plots per treatment for grasses and 15 replicates for sagebrush should be sufficient to detect at least a 20\% (Briggs and Knapp 1991) difference in productivity among treatments.

\section{Productivity and soil moisture}

Vegetative stem growth in sagebrush and above ground biomass in wheatgrass at controls increased significantly with spring recharge amounts (Fig. 1). No significant dependence of seed head production on soil moisture was found. However, seed head production increased significantly with higher biomass production ( $Y$ $\left.=11.6+0.3 \mathrm{X}, \mathrm{r}^{2}=0.34, \underline{\mathrm{t}}=2.50, \mathrm{t}_{0.05(1), 12}=1.78, \underline{\mathrm{P}}<0.025\right)$.

\section{Productivity and burrows}

When all sample pairs were used, the mean of the 6 average annual terminal growth estimates for sagebrush near burrows was a significant $0.6(\mathrm{SE}=0.11) \mathrm{cm}$ year $^{-1}$ longer than controls (Fig.2a). When the data sets were separated, in the group where recharge levels were higher for treatments, the mean stem growth of sage at burrows was still significantly longer $(1.0, \mathrm{SE}=0.15$ $\mathrm{cm}$ year-1) $^{-1}$ than controls (Fig. 2a). In the subset where spring recharge levels were higher at controls, stem growth did not significantly differ between treatment and control (Fig. 2a). For the grass experiment, there was a significant difference among the means of the annual average biomass and seed head (Fig. 2b) production for the control and three treatment levels for the 7 years under natural precipitation. Multiple range testing indicated significantly higher biomass in the 6 burrow treatment $\left(50.0 \mathrm{~g} \mathrm{~m}^{-}\right.$ 2 year $\left.{ }^{-1}, \mathrm{SE}=11.8\right)$ over the control $\left(42.6 \mathrm{~g} \mathrm{~m}^{-2}\right.$ year $^{-1}, \mathrm{SE}=$ 11.4) but could not detect differences among categories for seed head production. 

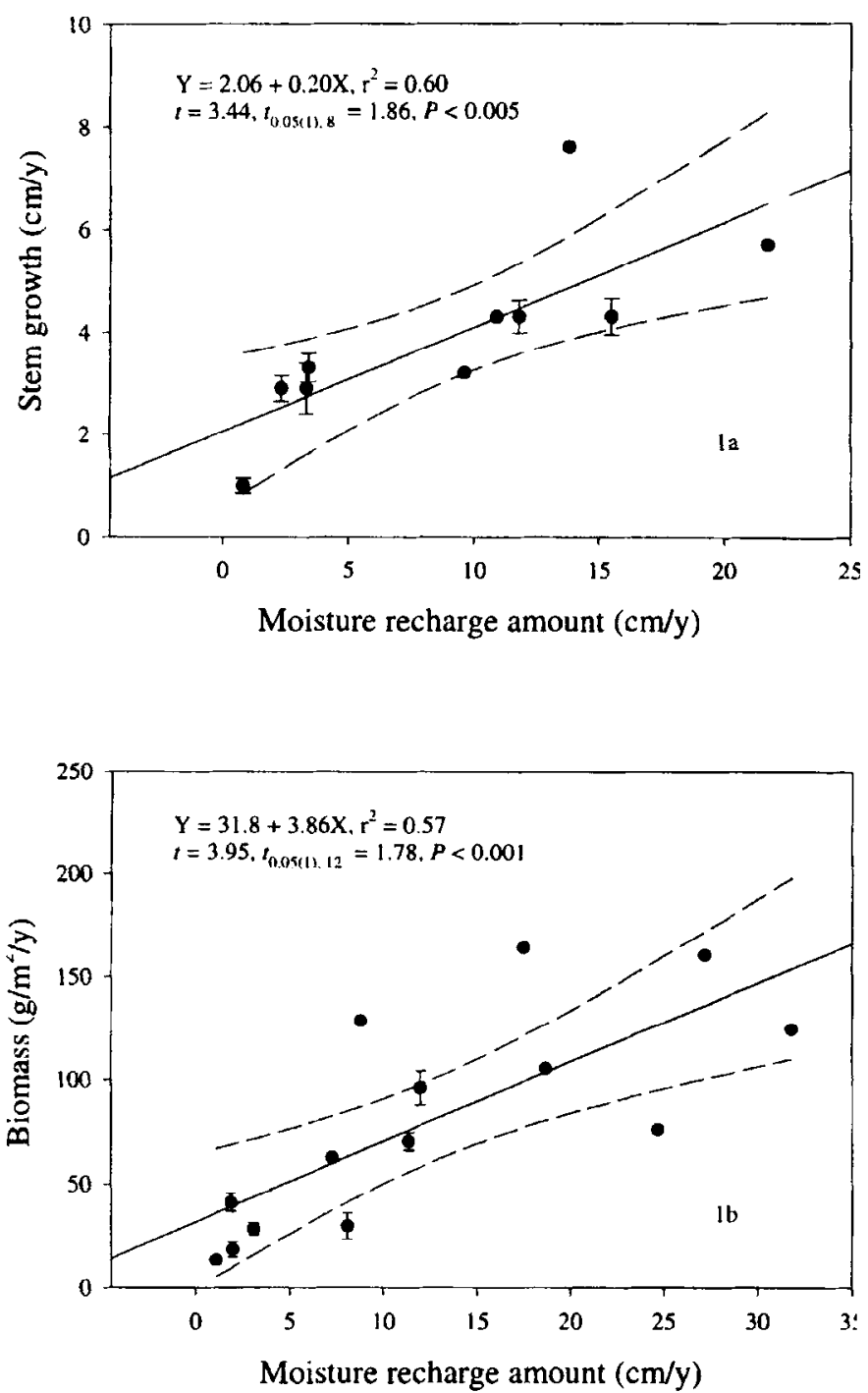

Fig. 1. Regression (with 95\% confidence intervals) of stem growth (a) and biomass production (b) on the INEEL against the amount of spring moisture recharge added to the soil profile. Only data from control sites were used and are 6 annual mean ( \pm SE indicated) estimates (1987-91 \& 1993) and 4 indiv:dual estimates of stem growth (1a) and 7 annual mean \pm SE indicated) estimates (1986$90 \& 1992-93$ ) and 7 individual estimates of biomass (1b). Individual estimates are from the 1991 growing season when snow pack was augmented unevenly on those control sites.

Because productivity between the control and treatments differed, I regressed the differences between the treatment values and controls with the corresponding differences in soil moisture. The only resulting regression equation that was significant and positive was for biomass production in the 6 burrow treatment vs control of the grass grid (Fig. 3).

\section{Discussion}

Numerous studies have demonstrated that productivity in a variety of plant species is directly related to precipitation amounts
(Sneva and Hyder 1962, Currie and Peterson 1966, Shiflet and Dietz 1974, Bamberg et al. 1976) and soil moisture (Rogler and Haas 1947). The results of this study indicate that for western wheatgrass and sagebrush in the semiarid shrub steppe, soil moisture levels at the beginning of the growing season can account for 57 to $60 \%$ of the variation in seasonal biomass productivity, respectively. For sagebrush, these findings differ from those of Evans and Black (1993) who found no effect of added moisture on biomass assimilation of vegetative stems. However, they did not add supplemental water until late spring (9 June) and early summer (4 July). Most of the vegetative stem growth in sagebrush is in early spring (Evans and Black 1993; personal observation) and would have already occurred by the time of their water treatments. Consequently, I concluded that the results I obtained represent the impact of spring moisture recharge differences on vegetative stem growth. These measures of productivity for both species could then be used to test if the increased soil moisture resulting from the presence of small mammal burrows and simulated burrows was sufficient to enhance plant productivity.

Comparisons of productivity between areas with and without burrows indicate that burrows do enhance productivity of sage-
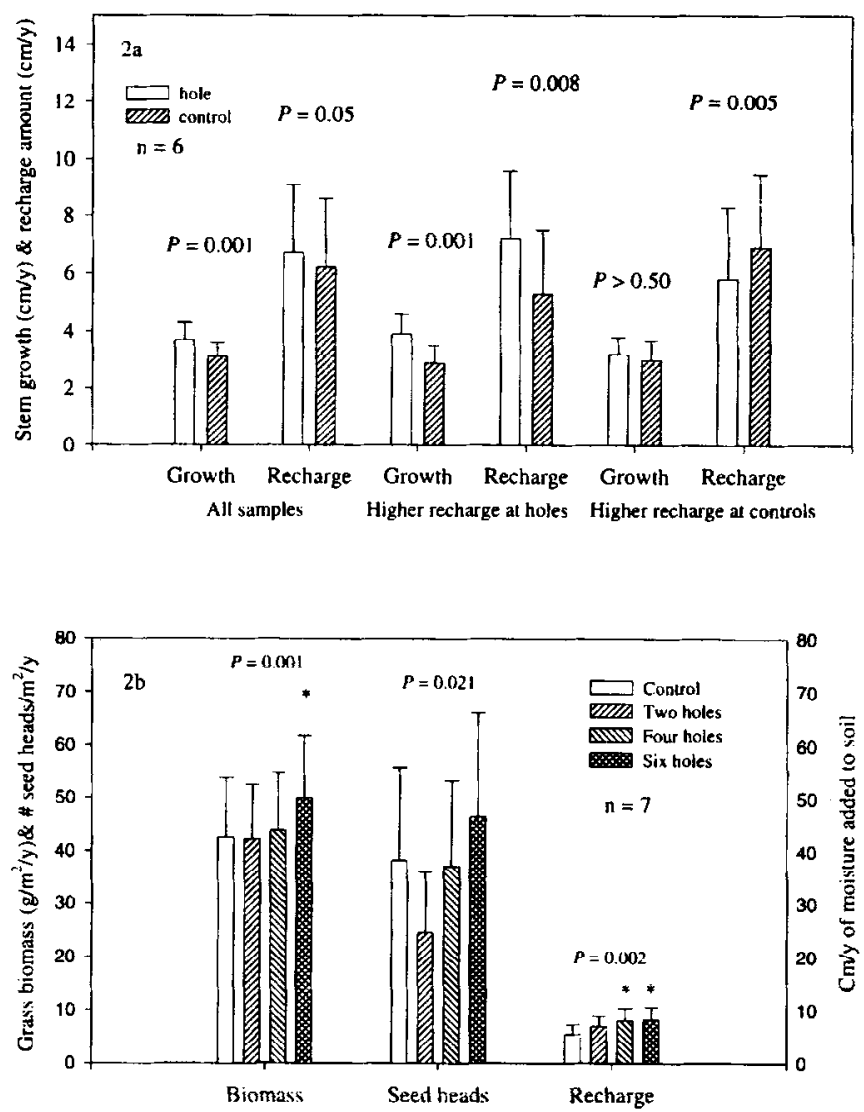

Fig. 2. Means ( \pm SE indicated) of annual average estimates of sagebrush growth (2a), biomass (2b), seed head production (2b) and soil moisture recharge levels of controls (without burrows) and burrow treatments in the INEEL. Data for sagebrush are from 6 years of the study (1987-91 \& 1993). Means for grass are of data for 7 years (1986-90 \& 1992-93). Unequal moisture recharge amounts on the grass grid from artificial snow pack efforts in 1991 precluded the use of data from that year. An asterisk indicates a treatment significantly different from other treatments. 


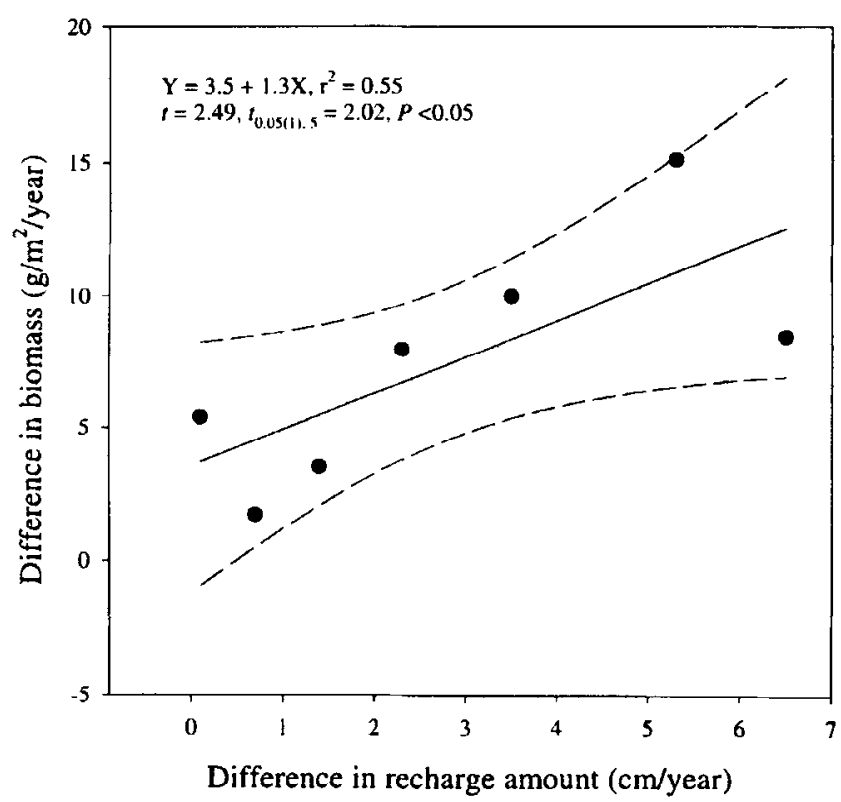

Fig. 3. Regression (with 95\% confidence intervals) of differences in mean biomass estimates from the INEEL between control grid cells and six hole treatments in the wheatgrass experiment against the corresponding differences in mean moisture recharge amounts.

brush. This especially became evident when sagebrush pairs where moisture was higher at burrows were analyzed separately. Sagebrush at burrows in these pairs produced terminal stems on average $1.0 \mathrm{~cm}$ year-1 longer than their nonburrow neighbors. In the study area where terminal stem growth rarely exceeds $5.0 \mathrm{~cm}$ year ${ }^{-1}$, this much additional growth can make a substantial difference in biomass production and possibly survival. It is of interest that in the subset where spring recharge levels were significantly higher at controls, sagebrush at burrows grew equally as well as controls but with less water available. Evidently, the other factors related to burrows, e.g. fecal and plant material deposition (Greene and Reynard 1932, Taylor 1935, Thorp 1949, Turner et al. 1973), soil mixing (Abaturov 1972, Hole 1981), and soil aeration (Inouye et al. 1987) are imparting advantages to associated plants which can produce similar increases with lower soil moisture. This would explain why the differences in stem growth of sagebrush from burrow areas over controls was not related in a predictable way to differences in soil moisture hetween treatment and control areas.

Productivity in western wheatgrass was also found to be enhanced by burrows, but only at the highest burrow density treatment. The higher productivity at this treatment was also directly related to the difference in soil moisture, above controls, added to the soil profile at the time of spring recharge. Relative to soil moisture in the artificial burrow experiment, the 2 hole artificial burrow treatment functioned similar to a single opening natural burrow system (Laundre 1993). However, in the absence of the other benefits of real burrows, the amount of increased moisture received in this treatment was evidently insufficient to enhance productivity. In the 4 hole treatment, there was a greater variability in spring recharge amounts than at the 6 hole level (Laundre 1993). At this lower density of burrows, other factors such as micro topography may affect pooling patterns and subse- quently the amount of moisture added to the soil and thus the corresponding summer productivity. This higher variability could mask any effect on productivity. Only at the highest burrow density did sufficiently more soil moisture consistently enter the soil to produce an observable effect. An alternate explanation is that the lack of predictable effects of increased soil moisture on productivity from lower density burrows may indicate that for western wheatgrass higher densities of burrow openings, e.g. colonial ground squirrels or species that construct multiple openings, may be required before an effect on productivity via increased spring recharge is seen.

In conclusion, the results support the hypothesis that burrows of Townsend's ground squirrels can enhance plant productivity in the cool desert environment of the Intermountain West. This enhancement is primarily through the burrows increasing spring recharge of moisture to the soil profile, but is likely augmented by the variety of other benefits derived from the presence of a burrow or its use by the animal. Townsend's ground squirrels primarily build their burrows adjacent to sagebrush plants on the INEEL (personal observation). This suggests a mutualistic interaction between the squirrels and their vegetal environment. Squirrels use live sagebrush for a burrow site and the presence of the burrow enhances the productivity of the individual bush. It is unknown at this time why animals select these sites and what impact the burrows might have on long term survival of the bushes. However, because their burrows can enhance growth and reproduction in plants, ground squirrels likely play a subtle role in community productivity and structure of semi-arid areas.

\section{Literature Cited}

Abaturov, B.D. 1972. The role of burrowing animals in the transport of mineral substances in the soil. Pedobiologia 12:261-266.

Anderson, J.E. and K.E. Holte. 1981. Vegetation development over 25 years without grazing on sagebrush-dominated rangeland in southeastern Idaho. J. Range Manage. 34:25-29.

Anderson, J.E., M.L. Shumar, N.L. Toft, and R.S. Nowak. 1987. Control of the soil water balance by sagebrush and three perennial grasses in a cold-desert environment. Arid Soil Res. Reh. 1:229-244.

Bamberg, S.A., A.T. Vollmer, G.E. Kleinkopf, and T.L. Ackerman. 1976. A comparison of seasonal primary production of Mojave Desert shrubs during wet and dry years. Amer. Mid. Nat. 95:398-405.

Briggs, J.M. and A.K. Knapp. 1991. Estimating aboveground biomass in tallgrass prairie with the harvest method: determining proper sample size using jackknifing and Monte Carlo simulations. Southw. Nat. 36:1-6.

Chew, R.M. 1978. The impact of small mammals on ecosystem structure and function. In: Snyder DP (ed) Populations of small mammals under natural conditions. Univer. Pittsburgh Press, Pittsburgh, Penn.

Currie, P.O. and G. Peterson. 1966. Using growing-season precipitation to predict crested wheatgrass yields. J. Range Manage. 19:284 288.

Evans, R.D. and R.A. Black. 1993. Growth, photosynthesis, and resource investment for vegetative and reproductive modules of Artemisia tridentata. Ecol. 74:1516-1528.

Fox, E., K Shotton, and C. Ulrich. 1995. Sigmastat user's manual. Jandel Corp. San Rafael, Calif.

Grant, W.E. 1974. The functional role of small mammals in grassland ecosystems. Dissertation. Colo. St. Univ., Fort Collins, Colo.

Green, R.A. and C. Reynard. 1932. The influence of two burrowing rodents, Dipodomys spectabilis spectabilis (Kangaroo Rat) and Neotoma albigula albigula (Pack Rat) on desert soils in Ariz. Ecol.13:73-80.

Hole, F.D. 1981. Effects of animals on soil. Geoderma 25:75-112. 
Huntly, N. and R.S. Inouye. 1988. Pocket gophers in ecosystems: patterns and mechanisms. BioScience 38:786-793.

Inouye, R.S., N.J. Huntly, D. Tilman, and J.R.Tester. 1987. Pocket gophers (Geomys bursarius), vegetation, and soil nitrogen along a successional sere in east central Minnesota. Oecologia 72:178-184.

Lane, L.J., E.M. Romney, and T.E. Hakonson. 1984. Water balance calculations and net production of perennial vegetation in the northern Mojave Desert. J. Range Manage. 37:12-18.

Laundre, J.W. 1993. Effects of small mammal burrows on water infiltration in a cool desert environment. Oecologia 94:43-48.

Rogler, G.A and H.J. Haas. 1947. Range production as related to soil moisture and precipitation on the northern great plains. J. Amer. Soc. Agron. 39:378-389.
Shiflet, T.N and H.E. Dietz. 1974. Relationship between precipitation and annual rangeland herbage production in southeastern Kansas. J. Range Manage. 27:272-276.

Sneva, F.A. and D.N. Hyder. 1962. Estimating herbage production on semiarid ranges in the intermountain region. J. Range Manage. 15:88-93.

Taylor, W.P. 1935. Some animal relations to soils. Ecol. 16:127-136.

Thorp, J. 1949. Effects of certain animals that live in soils. Sci. Month. 68:183-191.

Turner, G.T., R.M. Hansen, V.H. Reid, H.P.Tietjen, and A.L. Ward. 1973. Pocket gophers and Colorado mountain rangeland. Colo. St. Univ. Exp. Sta. Bull. 554S Fort Collins, Colo.

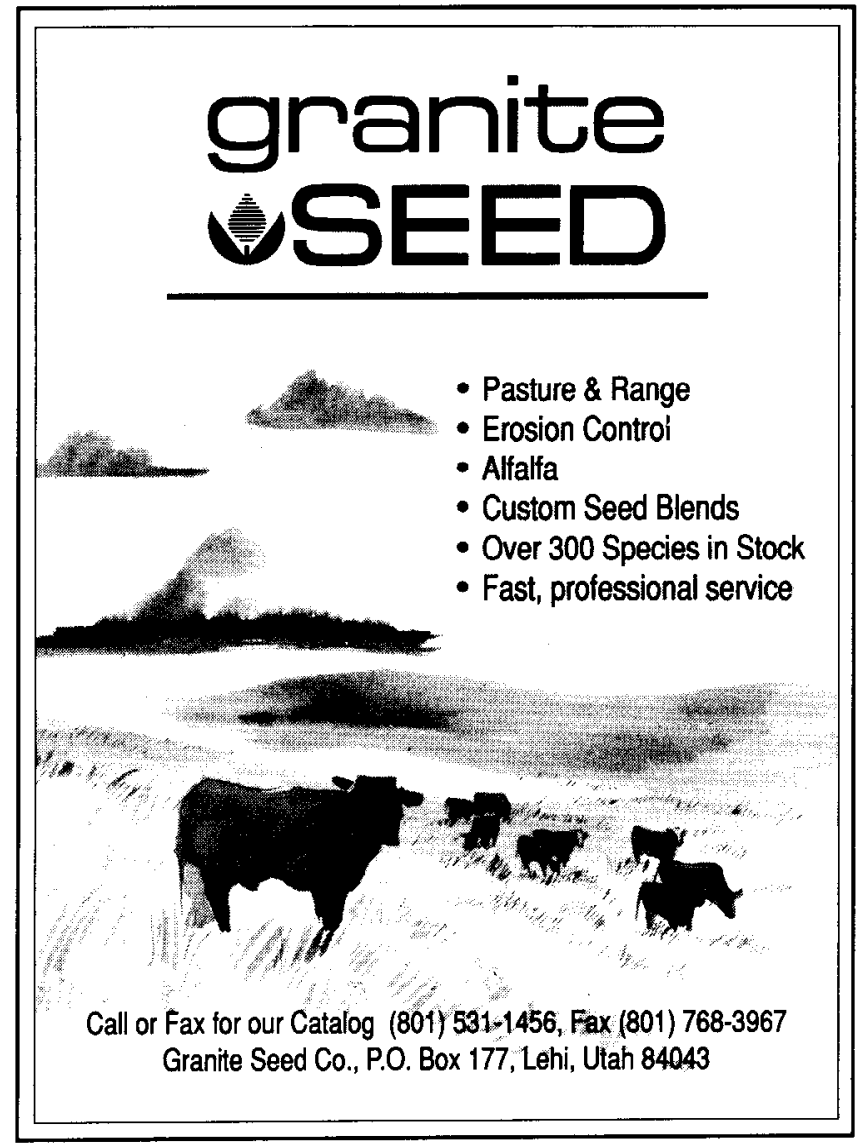

